\title{
The importance of behaving in a proactive way for marketing
}

\author{
management: the case of Thorntons PLC \\ Guochao Lin ${ }^{\text {a }}$ Qinping Chen ${ }^{b^{*}}$ \\ ${ }^{a}$ Fuzhou University of International Studies and Trade, China \\ ${ }^{\mathrm{b}}$ College of economic, Fujian Agriculture and Forestry University, China \\ *Corresponding author: Qinping Chen, Master, 354135780@qq.com
}

\begin{abstract}
Thorntons was positioned as luxury chocolate brands, however, it has continued to operate with a weak business performance in 2010-2012. The growing of products' volume and improvement of instore service cannot provide clear differences compared with its competitors. This paper took Thorntons as the research case, reviewed relevant studies and analysed the operation data from 20102012. finally, results found that lacking of product innovation is a continuing existing problem to influence the customers' choices. Although Thorntons has been in the hard economic environment and the increasingly complicated market, it still operated with a proactive marketing strategy. It is suggested that diverging sales channel to commercial customers deeply will expand the value of its brand and new market development. It is the power of behaving in a proactive way.
\end{abstract}

Key words: marketing management; proactive way; marketing strategy; business environment change

\section{Introduction}

Thorntons is a UK chocolate company which was once perceived as Chocolate Heaven by customers. In recent years, however, Thorntons has undergone a series of environmental changes which impact the company's performance, even the brand. Certainly, Thorntons has taken actions to respond these changes. This paper will examine the approach which the company has applied and then an evaluation will be further made for Thorntons' marketing strategy. Some innovative suggestions will be recommended to the marketing manager to remain competitive advantages in the domain of confectionery market. 


\section{Thorntons market activities and results}

Thorntons was positioned as luxury chocolate brands, however, in the past 3 years, it has continued to operate with a weak business performance ${ }^{1}$. The sales continued to decline by 0.5\% to $£ 217.1 \mathrm{~m}$ (2011: £218.3m), especially for the own stores and franchises. Total retail sales including own stores, franchise and Thorntons direct declined by $5.2 \%$ to $£ 132.1 \mathrm{~m}$ (2011: £139.5m). During that period, 36 stores were closed and three stores were refurbished, but just two of them were successful ${ }^{2}$. Finally, there were 330 stores at the end of the year (2011: 364 stores). Additionally, the profit before tax and exceptional items also decreased to $0.9 \mathrm{~m}$ (2011: 4.3m), which is a big drop in the past 3 years ${ }^{2}$.

Table 1 - Thorntons’ Key Performance Indicators (2010-2012) ${ }^{1}$

\begin{tabular}{|l|l|l|l|}
\hline & 2012 & 2011 & 2010 \\
\hline Net sales movement & $(0.5) \%$ & $1.7 \%$ & $(0.1) \%$ \\
\hline Own stores like for like sales growth & $(3.8) \%$ & $(7.9) \%$ & $(3.5) \%$ \\
\hline Profit before tax and exceptional items & $£ 0.9 \mathrm{~m}$ & $£ 4.3 \mathrm{~m}$ & $£ 6.9 \mathrm{~m}$ \\
\hline Gross margin return on sales & $44.0 \%$ & $46.2 \%$ & $49.7 \%$ \\
\hline Cash flow from operating activities & $£ 1.5 \mathrm{~m}$ & $£ 14.8 \mathrm{~m}$ & $£ 15.1 \mathrm{~m}$ \\
\hline
\end{tabular}

Table 2 - Thorntons' Revenue in Different Sectors (2010-2012) ${ }^{2}$

\begin{tabular}{|l|l|l|l|l|l|}
\hline & $\begin{array}{l}2012 \\
\text { Em }\end{array}$ & $\begin{array}{l}\text { \%increase/ } \\
\text { (decrease) }\end{array}$ & $\begin{array}{l}2011 \\
\text { Łm }\end{array}$ & $\begin{array}{l}\text { \%increase/ } \\
\text { (decrease) }\end{array}$ & $\begin{array}{l}2010 \\
\text { £m }\end{array}$ \\
\hline Own stores & 111.4 & $(5.8) \%$ & 118.3 & $(8.9) \%$ & 129.8 \\
\hline Franchise & 10.7 & $(7.8) \%$ & 11.6 & $(10.8) \%$ & 13.0 \\
\hline Thorntons Direct & 10.0 & $4.2 \%$ & 9.6 & $4.3 \%$ & 9.2 \\
\hline Total retail sales & 132.1 & $(5.2) \%$ & 139.5 & $(8.2) \%$ & 152.0 \\
\hline Sales \& operations & 85.0 & $7.9 \%$ & 78.8 & $25.9 \%$ & 62.6 \\
\hline Total sales & 217.1 & $(0.5) \%$ & 218.3 & $1.7 \%$ & 214.6 \\
\hline
\end{tabular}

Table 3 - Number of Thorntons' Outlets (2010-2012) ${ }^{2}$

\begin{tabular}{|l|l|l|l|}
\hline & 2012 & 2011 & 2010 \\
\hline Own stores & 330 & 364 & 377 \\
\hline Franchises & 177 & 227 & 222 \\
\hline
\end{tabular}

\section{Changes in environment forces}

In the past 3 years, some environmental factors have changed in Thorntons' development, which influenced the introduction and sales of the products. 


\subsection{Decline in discretionary income}

Since the UK economy moved into a double-dip recession, the impact of the economy weakness was felt across the company. Consumers' spending continued to be squeezed by a decrease in discretionary income ${ }^{3}$. For example, in the Christmas seasonal sales, customers purchased selectively which resulted in a higher proportion of sales coming from lower priced items and promotional lines, which means Thorntons lost sales of higher priced items.

\subsection{Stressful cost issues}

The increasing business costs, especially raw material cost, have put pressure on Thorntons' margins. For instance, the milk’s price has increased from 24.65 pence per litre in 2010 to 28.26 pence per litre in 2012. Combining with other product material cost like packaging materials, it seriously reduced the products’ profit margin.

\subsection{Change in consumer perception}

The increasing awareness of health has influence the customers' purchasing behavior. The targeted customers of women are changing their attitude on buying chocolate, who prefer noadded sugar and dairy free products. These have shifted the Thorntons products' introduction and sales procedures.

\section{Thorntons' actions}

In order to react the weakness in economy, Thorntons developed a multi-channel strategy to reduce the business. Since most of its own products are produced by Thorntons itself, the managers endeavor to create the opportunity to influence product costs. A number of actions have been taken to mitigate the pressures, including product and packaging engineering, ingredient optimisation, vertical integration and procurement initiatives ${ }^{4}$. In terms of packaging, Thorntons try to use more recycled materials in all components. Over 300 different raw materials are used in Thorntons' products, sourced by suppliers from all around the word.

Since customers trend toward healthy diet, Thorntons has development a 'kitchen' to create unique product. The 'Kitchen' targets in offering consumers various choices and expanding the product range, including organic, fair-trade, no added sugar and dairy-free products ${ }^{5}$. As Thorntons products are luxury gift items, they are not viewed as part of a balanced diet. Therefore, the company informed advice and detailed nutrition on the package so that 
customers can make an informed choice. Thorntons maintains health and good quality product through auditing and visiting over $95 \%$ of its suppliers.

\section{Behave in proactive way}

In general, there are two approaches towards changing environment. One is at the mercy of what the outside world delivers to business, which is known as reactive philosophy. On the contrary, business, which tends to collect information proactively to predict changes in the future and then adjusts strategies, is perceived as proactive performer ${ }^{6}$. Analyzing from previous parts, Thorntons was being proactive in its approach to its changing marketplace. This turns Thorntons into active position which gives a vital advantage in first strike despite of its high risk because performers predict changes in the future based on collected information ${ }^{7}$. Evidence and reasons are presented as follows:

\subsection{Marketing strategy readjustment according to market demand forecast}

As a season-driven business, Thorntons' sales of gift product would decrease with the wide range of gift market and consciousness desalination of season. Company consciously predicted the potential dilemma and developed series of non-seasonal products, such as ice cream and coffee shop instead of solely depending on sales promotion in order to compensate the seasonal sales. Multi-channel strategy particularly helped Thorntons out of seasonal limitation and proactively separate the risk. Such proactive approach based on adjusting sales structure, thus perceived as proactive response to the changing marketplace.

\subsection{Product readjustment according to customer perception forecast}

Social and economic factors have a far broader influence on global eating habits than ever before. People are attaching greater importance on healthy eating. Thorntons promptly recognized this transformation and embedded health philosophy into product development. No added sugar and dairy free products are the outstanding examples. Such proactive approach brought immense effects to Thorntons and helped company obtain wider customer base and continuous brand loyalty. Now more and more brands are reaping the rewards and other chocolate companies are scrambling to cash in on the trend as well. Thorntons acquired a vital advantage in health first strike. 


\subsection{Actively integration of new technology}

With the rapid growth of internet shopping, in 1998 Thorntons Direct, its commercial channel, commenced operations. In the era of Internet non popularization, Thorntons' decision played proactive role in the later development. Online shops still contribute considerable sales to the total sales revenue.

To sum up, Thorntons insists predicting changes based on their proactive activities and then making response. The driving philosophy of proactive approach determines company's position in the marketplace as a whole.

\section{Conclusions and recommendations}

There is no doubt that Thorntons put efforts to rebalance the sales and resources, revitalise the brand reputation and restore the profitability in industry competition. In order to remain competitive advantages in the marketplace, the following three suggestions are recommended:

\subsection{Enhance product innovation}

Since customers are becoming more and more sensitive to healthy issues, healthy product can become a new selling point. The compounds found in cocoa, the raw material of chocolate, can help treat diabetes, heart disease and some forms of dementia. What Thorntons should do is to deliver this unique selling point to their target customers, such as develop new recipes.

\subsection{Restructure stores' location}

The stores' structure problem with high vacancy and low customer flows seriously affect the company's performance. Thorntons should continue to close those idle shops to reduce the wastes of operating. Resources should be reallocated to reshape those well-performed shops to improve the customer services.

\subsection{Revitalise brand building}

Currently, the sales are mostly driven by seasonal products, various seasonal promotion made both customers and company fatigue to pursue limited profit margin. This made Thorntons deviate the original mission and will reduce the customers' perceived value. As Thorntons positioned itself as a luxury brand, it is impossible for one brand to target two position. Thorntons should reconsider its brand mission to focus on the target position more specificity. 


\section{References}

1. G.Charles, Thorntons: Business is less than sweet in the downturn. Market watch: Global roundup, (2009) 8(4), 73.

2. C.Hughes, Proactive or reactive management. Business Matters, (2004) 64(3), 14.

3. A.Conti, A.Poli, (ed.) Chocolate and Health. Dordrecht: Springer. (2012) 78-91.

4. World Bank. World development report 1993. Investing in health: world development indicators. New York: Oxford University Press for World Bank. (1993) 199-205.

5. Defra, United Kingdom Milk Prices and Composition of Milk. URL: www. Defra.gov.uk (29. 7. 2017)

6. J. Kollewe, Thorntons hit by falling profits and store closures. URL: http://www.guardian.co.uk/Business/2011/dec/21/thorntons-falling-profits-storeclosures?INTCMP=ILCNETTXT3487(29. 7. 2017)

7. T.Richardson, Where did Thornton go wrong. URL: http://www.guardian.co.uk/commentisfree/2011/jun/29/where-did-thorntons-chocolate-gowrong (29. 7. 2017) 